\title{
Financial Institutions, Contagious Risks, and Financial Crises
}

\author{
By: Haizhou Huang and Chenggang Xu
}

William Davidson Working Paper Number 444

November 2001 


\title{
Financial Institutions, Contagious Risks, and Financial Crises ${ }^{1}$
}

\author{
Haizhou Huang \\ Monetary and Exchange Affairs Department \\ International Monetary Fund \\ $70019^{\text {th }}$ Street, NW \\ Washington, DC 20431, U.S.A. \\ hhuang@,imf.org
}

\author{
Chenggang $\mathrm{Xu}$ \\ Department of Economics \\ London School of Economics \\ Houghton Street \\ London WC2A 2AE, U.K. \\ c.xu@1se.ac.uk
}

First draft: October 1998; Revised: November 2001

\begin{abstract}
In this paper contagious risks and financial crises are endogenized through the interactions among corporations, banks, and the interbank market. We show that the lack of financial discipline in a single-bank-financing economy generates informational problems and thus the malfunction of the interbank market, which constitutes a mechanism of financial contagion and may lead to a financial crisis. In contrast, financial discipline in an economy with diversified financial institutions leads to timely information disclosure from firms to banks and improves the informational environment of the interbank market. With symmetric information in the interbank market, bank runs are contained to insolvent banks and financial crises are prevented. Our theory sheds light on the causes and timing of the East Asian crisis; it also has important policy implications for the lender of last resort and banking reform.
\end{abstract}

Key words: financial institutions, contagious risks, financial crises

\footnotetext{
${ }^{1}$ We are grateful to William Alexander, Abhijit Banerjee, Sudipto Bhattacharya, Peter Clark, Tito Cordella, Xavier Freixas, Charles Goodhart, James Gordon, Nich Hope, Barry Johnston, Nobu Kiyotaki, Janos Kornai, Michael Manove, Eric Maskin, John Moore, George Pennacchi, Dwight Perkins, Katharina Pistor, Yingyi Qian, Jean-Charles Rochet, and Jean Tirole for helpful comments; to the seminar and conference participants at the AEA Conference, CEPR Conference in Financial Regulation (Tenerife), EEA Conference, JFI Symposium (Ann Arbor), Harvard, IMF, Illinois, LSE, Peking, Stanford, Southampton, Toulouse, and USC, and to Nancy Hearst for editorial assistance. The second author thanks the hospitality of the Research Department of the IMF; the support of the CID and HIID at Harvard, and the CEP at LSE. The views are those of the authors and do not necessarily represent those of the IMF or IMF policy. All errors are unfortunately the authors as well.
} 


\section{Non-Technical summary}

It has been documented that financial crises often accompany problems in financial institutions, probably even more so at some specific stages of development. The recent financial crisis in East Asia, as well as the major financial crises in Europe and America in the late 1920s and earlier, provide examples but and the recent Asian crisis also poses new challenges to economists and policy makers. For example, immediately before the crisis, the East Asian economies had been doing so well that there was a major debate among economists concerning the nature of the "miracle." The eruption of the financial crisis in East Asia presents a major challenge to economists and policy makers. A particularly puzzling phenomenon regarding the crisis is derived from a comparison between Korea and Taiwan. Korea and Taiwan were both regarded as the major phenomenon of the so-called "East Asia Miracle." However, while Korea was at the center of the East Asian crisis, Taiwan was much less affected --- even though it too had been attacked by international speculators. Was this difference an accident?

Our analysis of the functions of corporate and banking institutions will provide an answer to this puzzling phenomenon. Consistent with observations that the financial crisis in East Asia was deeply linked to corporate financial problems, our theory suggests that different financing structures in the various East Asian economies generated a profound impact on the information in their respective financial markets, which further affected financial stability.

Our theory can be summarized as follows. Informational structures in two different kind of economies are endogenized. In an economy where corporations are financed by multiple banks or through a syndicated loan, the liquidation of bad projects/firms is a norm in the economy. The liquidation of bad projects makes information public so that banks have more knowledge about each another's assets and solvency. In the remainder of the paper, we term this kind of economy a multi-bank-finance (MBF) economy.

In an economy where financing decisions of corporations are concentrated (e.g., the Japanese main-bank system or the Korean principal-transaction-bank system), however, the liquidation of bad projects/firms is an exception. Without the liquidation of bad projects, banks with bad projects can easily hide bad news from others. We show that in such an economy bad projects are not liquidated and thus the solvency of a financier is not known to other financiers. We call this kind of economy a single-bank-finance economy (SBF).

In our model, an economy has many banks which receive deposits a la Diamond and Dybvig, 1983 ) and invest in long-term projects with stochastic returns. Moreover, there is an interbank market which may solve liquidity shortage problems among banks. That is, when a bank faces a liquidity shock it may borrow from others in the market. The function of the interbank market depends on information about the asset quality of the borrowing bank. When an equilibrium is such that bad projects are liquidated (e.g., in MBF economy), which can be observed by other banks, the interbank market can function well and trading among banks can solve the liquidity problem faced by illiquid banks. 
However, if lending banks in the interbank market are unable to distinguish solvent from insolvent borrowing banks (e.g., in a SBF economy), i.e., there is a pooling equilibrium whereby all illiquid banks are treated in the same manner. In that case, asymmetric information among financiers will make the interbank lending market a "lemon" market. In this lemon market, all borrowing banks face the same nominal expected cost. This implies that solvent banks will have to subsidize the borrowing of insolvent banks. With private information about one's own solvency, a better-quality borrowing bank will face higher costs of borrowing due to this implicit subsidy.

When a liquidity shock is severe, such high borrowing costs can lead a solvent bank to choose between liquidating assets or facing a bank run. Since bank managers have career concerns and from their perspective, a liquidation is worse than a bank run. As a result, illiquid banks with better-quality assets may not borrow and may face a bank run earlier than other banks. However, a bank run on better banks will deteriorate the quality of the lending market, thus triggering more bank runs. We further demonstrate bank run contagious risks can lead to the collapse of the lending market and a financial crisis, in particular when investment projects are heterogeneous in quality.

We also show that a pooling equilibrium in the interbank market does not always lead to a financial crisis when there are only idiosyncratic shocks and the projects are homogeneous in quality. This is because the expected borrowing cost for good banks decreases monotonically with the average quality of the projects in the economy and the homogeneity of the quality of projects. If the average quality of the projects is high, and/or the projects are very homogeneous in quality, the interbank market works well and there is no bank run or financial crisis. But if the projects are heterogeneous and the average quality of the projects is not very high, a pooling equilibrium in the interbank market becomes an incubator for a financial crisis.

This result has implications for the timing of a financial crisis in a pooling equilibrium economy. An economy should have no trouble when most of its sectors are similar, e.g., most projects are at similar imitation stages, but the situation will change when the projects are more heterogeneous, such as when the imitation stage of the economy has ended.

One of our major contributions to the literature is to model the function and failure of the interbank market with the presence of both liquidity and technological shocks and imperfect information. We show that a certain type of financial institution (MBF) creates symmetric information in the interbank lending market; in that case bank runs are contained. We endogenize Akerlof's (1970) lemon problem and extend it from real markets to the liquidity market between lenders and borrowers. A contagious bank run in our model is the result of an interbank market failure due to informational problems, which are caused by a SBF institution. In a separate paper, we further extend our analysis of the liquidity management of banks in a model with an interbank market and liquidation of real assets. Another contribution is to provide a model to illustrate that a commitment mechanism to liquidate bad projects can make solvency information available to the market on a timely basis. 


\section{William Davidson Institute Working Paper 444}

\section{INTRODUCTION}

It has been documented that financial crises often accompany problems in financial institutions, probably even more so at some specific stages of development. The recent financial crisis in East Asia, and the major financial crises in Europe and America in the late 1920s and earlier, provide examples. This paper develops a theory which endogenizes financial crises through institutions related to the corporate sector, banks, and the interbank market. The basic idea is that different ways of financing corporate investment projects may affect the nature of bankruptcy in failing projects. This in turn affects information in the interbank market. For financial institutions unable to commit to liquidate bad projects, there will be informational problems between entrepreneurs and banks, which will cause informational problems among banks in the interbank market. Severe informational problems in the interbank market can lead to a market failure, which constitutes a mechanism for financial contagion and creates conditions for a financial crisis.

Our theory emphasizes the role of financial institutions in explaining financial crises, in particular the 1997 East Asian financial crisis. Immediately before the crisis, the East Asian economies had been doing so well that there was a major debate among economists concerning the nature of the "miracle." The eruption of the financial crisis in East Asia presents a major challenge to economists and policy makers. A particularly puzzling phenomenon regarding the crisis is derived from a comparison between Korea and Taiwan. Korea and Taiwan were both regarded as the major phenomenon of the so-called "East Asia Miracle." However, while Korea was at the center of the East Asian crisis, Taiwan was much less affected - even though it too had been attacked by international speculators.

Was this difference an accident? Our analysis of the functions of corporate and banking institutions will provide an answer to this puzzling phenomenon. Consistent with observations that the financial crisis in East Asia was deeply linked to corporate financial problems, our theory suggests that different financing structures in the var- 


\section{William Davidson Institute Working Paper 444}

ious East Asian economies generated a profound impact on the information in their respective financial markets, which further affected financial stability.

Our theory can be summarized as follows. Informational structures in two different kind of economies are endogenized. In an economy where corporations are financed by multiple banks or through a syndicated loan, the liquidation of bad projects/firms is a norm in the economy (see the model). The liquidation of bad projects makes information public so that banks have more knowledge about each another's assets and solvency. In the remainder of the paper, we term this kind of economy a multibank-finance (MBF) economy.

In an economy where financing decisions of corporations are concentrated (e.g., the Japanese main-bank system or the Korean principal-transaction-bank system), however, the liquidation of bad projects/firms is an exception (see the model). Without the liquidation of bad projects, banks with bad projects can easily hide bad news from others. We show that in such an economy bad projects are not liquidated and thus the solvency of a financier is not known to other financiers. In the remainder of the paper, we call this kind of economy a single-bank-finance economy (SBF).

In our model, an economy has many banks which receive deposits ( $\grave{a}$ la Diamond and Dybvig, 1983) and invest in long-term projects with stochastic returns. Moreover, there is an interbank market which may solve liquidity shortage problems among banks. That is, when a bank faces a liquidity shock it may borrow from others in the market. The function of the interbank market depends on information about the asset quality of the borrowing bank. When an equilibrium is such that bad projects are liquidated (e.g., in MBF economy), which can be observed by other banks, the interbank market can function well and trading among banks can solve the liquidity problem faced by illiquid banks.

However, if lending banks in the interbank market are unable to distinguish solvent from insolvent borrowing banks (e.g., in a SBF economy), i.e., there is a pooling equilibrium whereby all illiquid banks are treated in the same manner. In that case, asymmetric information among financiers will make the interbank lending market a 


\section{William Davidson Institute Working Paper 444}

"lemon" market. In this lemon market, all borrowing banks face the same nominal expected cost. This implies that solvent banks will have to subsidize the borrowing of insolvent banks. With private information about one's own solvency, a better-quality borrowing bank will face higher costs of borrowing due to this implicit subsidy.

When a liquidity shock is severe, such high borrowing costs can lead a solvent bank to choose between liquidating assets or facing a bank run. We assume that a liquidation implies poor management, while a well-managed bank can still experience a bank run due to exogenous liquidity shocks. In addition, bank managers have career concerns. Thus, from a bank manager's perspective, a liquidation is worse than a bank run. As a result, illiquid banks with better-quality assets may not borrow and may face a bank run earlier than other banks. However, a bank run on better banks will deteriorate the quality of the lending market, thus triggering more bank runs. We further demonstrate bank run contagious risks can lead to the collapse of the lending market and a financial crisis, in particular when investment projects are heterogeneous in quality.

We also show that a pooling equilibrium in the interbank market does not always lead to a financial crisis when there are only idiosyncratic shocks and the projects are homogeneous in quality. This is because the expected borrowing cost for good banks decreases monotonically with the average quality of the projects in the economy and the homogeneity of the quality of projects. If the average quality of the projects is high, and/or the projects are very homogeneous in quality, the interbank market works well and there is no bank run or financial crisis. But if the projects are heterogeneous and the average quality of the projects is not very high, a pooling equilibrium in the interbank market becomes an incubator for a financial crisis.

This result has implications for the timing of a financial crisis in a pooling equilibrium economy. An economy should have no trouble when most of its sectors are similar, e.g., most projects are at similar imitation stages, but the situation will change when the projects are more heterogeneous, such as when the imitation stage of the economy has ended. 


\section{William Davidson Institute Working Paper 444}

One of our major contributions to the literature is to model the function and failure of the interbank market with the presence of both liquidity and technological shocks and imperfect information. ${ }^{1}$ We show that a certain type of financial institution $(\mathrm{MBF})$ creates symmetric information in the interbank lending market; in that case bank runs are contained. We endogenize Akerlof's (1970) lemon problem and extend it from real markets to the liquidity market between lenders and borrowers. A contagious bank run in our model is the result of an interbank market failure due to informational problems, which are caused by a SBF institution. In a separate paper (Huang and $\mathrm{Xu}, 2001$ ), we further extend our analysis of the liquidity management of banks in a model with an interbank market and liquidation of real assets.

Von Hayek (1945) outlined a principle according to which it is the market, rather than the government, that provides the right information for the economy to operate efficiently. However, what this means in the context of a financial crisis is unclear. One of our major contributions is to provide a model to illustrate that a commitment mechanism to liquidate bad projects can make solvency information available to the market on a timely basis.

With respect to the recent literature on financial crisis, the works by Aghion, Bolton, and Dewatripont (1999) and Allen and Gale (2000) are related to our work, but their emphases are different from ours. Aghion, Bolton, and Dewatripont (1999) focus on systemic shocks to the entire banking system. In comparison, we study a mechanism of negative externalities in the interbank market that transforms idiosyncratic shocks into a systemic liquidity shock, and thus bank failure contagion. Allen and Gale (2000) derive financial contagion from the incompleteness of the structure of interregional claims. If we reinterpret our interbank market as a form of interconnectedness among all the banks in their model, then we show that even with a complete structure of interregional claims, informational problems in the market can still lead to financial contagion.

\footnotetext{
${ }^{1}$ See Bhattacharya and Gale (1987) and Rochet and Tirole (1996) for contributions on modeling the interbank market with liquidity trading.
} 


\section{William Davidson Institute Working Paper 444}

Finally, in the following we summarize our way of endogenizing pooling and separating equilibria in the interbank market. A financial system where key decisions on project refinancing are made by "multi banks" incurs higher costs of renegotiation, hence liquidations are more likely to occur. That is, multi-bank financing can be used as a commitment device to create a separating equilibrium. In contrast, financial systems where key decisions are made by single banks do not face such high renegotiation costs and thus are more likely to reorganize rather than to liquidate. That is, the system is not able to commit to stopping bad projects, and therefore good and bad projects are pooled together. Examples of such single-bank systems include the main-bank system in Japan and the principal-transaction-bank system in Korea.

To focus on our major points, we analyze two types of a "pure" economy: a SBF economy in which only a pure pooling equilibrium exists, and a MBF economy in which only a pure separating equilibrium exists. We also suppose that the choice of a financial system in an economy depends on some exogenous reasons that make multi-bank financing too costly, such as high costs to enforce contracts. The idea to use multi-bank financing as a commitment device is inspired by Dewatripont and Maskin (1995), Hart and Moore (1995), and Bolton and Scharfstein (1996).

The rest of the paper is organized as follows. Section 2 briefly overviews financial institutions in Korea and Taiwan. Section 3 establishes the basic structure of the model and endogenizes information distributions between banks and corpora-

tions and in an interbank market. Section 4, in particular subsections 4.3 and 4.4, investigates how a bank run contagion is created in a SBF economy and when it can lead to a financial crisis. Finally, section 5 concludes with some qualifications and elaborations of our theory in relation to the existing literature, and a discussion of policy implications. 


\section{William Davidson Institute Working Paper 444}

\section{FINANCIAL INSTITUTIONS AND CORPORATE FINANCING IN KOREA AND TAIWAN}

Korea and Taiwan are at similar development stages, geographically close, and they also have similar technologies, labor inputs, and high savings. In both economies the share of trade in GNP is much higher than the world average; and each economy has been transformed from a developing economy into a high-tech oriented economy. Moreover, both were regarded as the major phenomenon of the so-called "East Asia miracle." However, while Korea was at the center of the East Asian crisis, Taiwan was much less affected - even though it too has been attacked by international speculators. Is this difference an accident?

In this section we present brief overviews of the Korean and Taiwanese economies to illustrate that their financial institutions are quite different, and to show how this difference may related to their different performances in the East Asia financial crisis.

It is well documented that Korean development has been characterized by the establishment of large conglomerates (chaebols) through government-coordinated bank loans. In a typical case, financing decisions for projects in Korea are made by the government or by the principal bank among a group of investing banks. For example, in the 1970s the Korean government promoted investment in the heavy and chemical industries by selecting projects and providing subsidized loans. In the 1980s the government promoted specialization in the largest chaebols through a similar financing approach. In the two decades since the early 1970s, more than half of Korean domestic credits were distributed as government policy loans with low rates (Stern et al., 1995; Cho and Kim, 1995). ${ }^{2}$ It is well documented that the decision making of policy loans was concentrated in the hands of the government.

\footnotetext{
${ }^{2}$ A closely related fact is that since the 1970s Korean firms were over-leveraged as their average debt-equity ratio was among the highest in the world (Borensztein and Lee, 1998; Lee, 1998). Before the outbreak of the 1997 crisis the average debt-equity ratio of the thirty top chaebols was about 4.5. Moreover, a recent econometric study shows that a significant part of the total credit in Korea was not used productively (Demetriades and Fattouh, 1998).
} 


\section{William Davidson Institute Working Paper 444}

The subsidized government loans led to distortions in the corporate capital structure: between 1965 and 1970, as the debt-equity ratio of manufacturing firms in Korea increased from 0.94 to 3.29 (Nam and Kim, 1994). To reform the inefficient loan allocation scheme, the Korean government established a credit control system called a "principal-transactions-bank system" in the mid-1970s. Under this system, the bank which was most involved financially with each chaebol was designated as the principal-transactions bank to coordinate all lending activities. Any new credit to be issued by a bank to the chaebol was supposed to be evaluated by the principal bank. However, this principal-transactions-bank system was not substantially different from the government-coordinated financing scheme. That is, financing decisions were concentrated in either the government or the principal bank.

Although there were complaints that with a predominance of government coordinated bank financing, credits were not allocated efficiently to Korean firms, ${ }^{3}$ the great success in the period from the 1960s to the mid 1990s was obvious. Problems in the corporate financing structure only became evident to outsiders when the East Asian financial crisis hit Korea. Some Korean economists claimed that excessive credit expansions caused the insolvency of 5 the top 30 and of 7 of the top 50 chaebols; it has been documented that the insolvent chaebols had debt-equity ratios from 5.14 to 36, while the average of the 30 top chaebols was about 4.49 in April 1997 (Park, 1997, p.1). It follows to question why creditors would be willing to continue providing credit to insolvent or nearly insolvent chaebols? Closely related to the high debt financing is the fact that there was almost no bankruptcy in Korea before 1997 (particularly for the chaebols).

\footnotetext{
${ }^{3}$ Using panel data of thirty-two Korean manufacturing sectors for the period from 1969 to 1996 , Borensztein and Lee (1998) show that credit was allocated preferentially to sectors with larger firms, with exports, or with poor economic performance. Examining firm-level data for the 1984 - 86 period, Dailami and Kim (1994) discover that subsidized credit encouraged the chaebols to hold more financial assets and real estate investments, but not actual productive assets.
} 


\section{William Davidson Institute Working Paper 444}

\section{Major Insolvent Chaebols}

\begin{tabular}{|l|l|l|l|l|l|l|}
\hline & Hanbo & Usong & Sammi & Jinro & Taenong & Kia \\
\hline Asset Ranking & 14 & 27 & 26 & 19 & 33 & 8 \\
\hline Debt/Equity & 6.75 & 17.1 & 32.3 & 36.0 & 18.2 & 5.14 \\
\hline
\end{tabular}

Source: Kyong-so Park (1997), p.1. ${ }^{4}$

Systematic evidence indeed suggests that the closing down of Korean plants was not related to financial discipline. From panel data of more than 40,000 Korean manufacturing plants for the 1983 - 1993 period, Aw, Chung, and Roberts (1998) discover that the productivity of the plants being closed down was about the same as those in operation. This suggests that decisions involving the closure of plants were not related to efficiency considerations.

Compared with Korea, Taiwan firms relied on much more diversified financial sources. Creditors in Taiwan were not coordinated by the government or other agents (a Japanese type of main-bank system does not exist in Taiwan). Even the state-owned banks were supposed to make financing decisions on their own. In addition, equity financing played a much larger role in Taiwan - the average debt-equity ratio of all Taiwan firms during the 1985 - 1992 period was about 1.4 and the ratio of the large firms was even lower (about 1.2) (Semkow, 1994, p.84).

Moreover, firms in Taiwan were subject to effective financial discipline and thus there had been frequent bankruptcies in the corporate sector over the past several decades. Inefficient firms were indeed disciplined: the productivity of closed-down (disciplined) firms was 11.4 percent to 15.5 percent lower than that of other firms (Aw et al., 1998).

We believe that the different financial structures in the two economies provide

\footnotetext{
${ }^{4}$ Closely connected to the inefficiencies of the projects being invested in, the losses from projects financed by bank loans caused serious problems for the Korean banks. At the end of 1986, nonperforming loans at the five largest commercial banks amounted to three times the total net worth of those banks (Park and Kim, 1994). To relieve the troubled banks, between 1985 and 1987 the Bank of Korea provided them with more than 3 trillion won in subsidized loans (Nam, 1994).
} 


\section{William Davidson Institute Working Paper 444}

important clues to explain their different performances in the East Asian financial crisis. In the remainder of the paper, we will attempt to explain how corporate financing determines the financial discipline of firms, and how this is related to financial stability.

\section{THE MODEL}

\subsection{The Basic Setup}

We consider a one-good economy, which has many entrepreneurs, $M$ banks and bank managers, and $N \times M$ depositors. Since entrepreneurs have ideas about new investment projects but no wealth to finance them, a project can be financed either by one bank alone or by two (or more banks) jointly. In this model any uncertain investment can be a project, such as an investment in technological innovation or imitation. Among all the projects proposed by entrepreneurs, $\lambda_{o}$ percentage of the projects are of a good type, and the rest are of a bad type. Ex ante, neither entrepreneurs nor banks know which projects are good and which projects are bad, but they both are fully aware of the probability of the distribution of the projects.

A project takes three periods to finish, requiring a total investment of $I=I_{1}+$ $I_{2}+I_{3}$, where $I_{t}$ is the required investment in period $t$, and $I_{t} \gg 1$. The technology of the project has a constant return to scale. A good project generates an ex-ante profitable return, $Y>I$, while a bad project generates no return as it stands.

For a project being financed, we assume that at date 1 an entrepreneur will learn its type, while the bank(s) still will not know its type. However, at date 2, the bank(s) will know the type of the project. If the project is of a bad type, it can be reorganized at date 2 and the best return a reorganized bad project can generate is $X$, and $I_{3}<X<I_{2}+I_{3}$, that is, it is ex-ante unprofitable but ex-post profitable. Therefore, at date 2 a decision has to be made by the bank(s) regarding a bad project: either to reorganize it or to liquidate it. ${ }^{5}$

\footnotetext{
${ }^{5}$ The setup of our model shares some features with Qian and $\mathrm{Xu}$ (1998), which is based on
} 


\section{William Davidson Institute Working Paper 444}

With respect to reorganization, we assume that there are two strategies $a$ and $b$ to reorganize a bad project during the third period, but only one of them can generate a profit ex post. The selection by the bank(s) of a specific strategy depends on their information. We suppose that in the case of co-financing, banks $A$ and $B$ will observe different information, represented by signals $s_{A}$ and $s_{B}$ respectively, where $s_{J} \in[\underline{s}, \bar{s}]$, $\underline{s}<\bar{s}$ and $J=A, B$, after $I_{3}$ is invested.

We suppose that an entrepreneur gets a private benefit $b_{t}$ from working on a project, where $t$ denotes the date when the project is either completed or terminated at $t=1,2,3 .^{6}$ Specifically, at date 1 if the entrepreneur quits the project, he gets a low private benefit, $b_{1}>0$. At date 2 , if a bad project is liquidated, the entrepreneur gets an even lower private benefit $b_{2 b}$, where $0 \leq b_{2 b}<b_{1}$. At date 3 , if a bad project is reorganized and completed, it will generate a private benefit $b_{3 b}>b_{1}$ to the entrepreneur; in the case of a good project, it will generate a private benefit, $b_{3 g}>b_{3 b}$, to the entrepreneur. To summarize, we have $b_{3 g}>b_{3 b}>b_{1}>b_{2 b} \geq 0$.

In this economy, banks exist because they create liquidity and monitor investments on behalf of small depositors (Diamond, 1984; Gorton and Pennacchi, 1990). ${ }^{7}$ Bank managers are hired to manage banks, to make investment decisions, and to monitor bank investments in firms. They are risk-neutral, and they do not want to be identified as bad managers (e.g., career concerns).

All the $M$ banks in the economy are ex-ante identical. Each bank has $N$ depositors, and according to banking regulation rules each bank has $K>0$ initial bank capital, the role of which will become clearer later. Each depositor deposits $\$ 1$ in a bank, thus each bank's asset is $\$(N+K)$. The $M$ banks form an interbank market to trade liquidity. We assume that the liquidation of a bad project is observable by all the banks; while without liquidation the nature of a project financed by a bank is

the Dewatripont-Maskin contractual foundation, but this paper establishes a different contractual foundation for the commitment problem.

${ }^{6}$ We use the term private benefit in a general way such that it includes both rewards and penalties.

${ }^{7}$ See Bhatacharya and Thakor (1993) for an excellent survey of the recent literature on contemporary banking theory. 


\section{William Davidson Institute Working Paper 444}

not observable by any bank that is not involved in the investment and monitoring of the project.

In our economy there are two types of risk-averse depositors, as described by Diamond and Dybvig (1983): early consumers only consuming at $t=1$, and late consumers only consuming at $t=3$. Ex ante, all depositors are identical and do not become aware of their types until $t=1$. Moreover, each depositor's $\$ 1$ endowment can be stored from one period to the next, without any cost, or it can be deposited in a bank that may generate a positive return $R$ at date $3 .^{8}$ They make their investment decision based on an ex-ante belief about the riskiness of the banking system and about the market equilibrium returns on deposits. They supposedly do not have the required expertise to be entrepreneurs or bank managers, nor do they monitor banks because of high surveillance costs or/and lack of knowledge.

Each depositor's preference is defined as

$$
U=\pi_{1} u\left(C_{1}\right)+\rho \pi_{2} u\left(C_{2}\right),
$$

where $C_{j}$ is the consumption of type $j$ depositor; $j=1$ being early consumers who consume at $t=1$ and $j=2$ being late consumers who consume at $t=3 ; \pi_{j}$ is the probability of a depositor being a type 1 or type 2 consumer, and $\pi_{1}+\pi_{2}=1$; $\rho<1$ is the discount factor and $\rho(R+1)>1$; and $u^{\prime}>0, u^{\prime \prime}<0$, and $\left(C u^{\prime}\right)^{\prime}=u^{\prime}+C u^{\prime \prime}<0$.

Now we summarize the timing of the game as follows:

- Date 0: All parties know the probability of the distribution of the projects and the depositors, but no one knows the type of each project and the type of each depositor. The bank(s) offer a take-it-or-leave-it contract to the entrepreneur. If the contract is signed, the bank(s) will invest $I_{1}$ units of money into the project during period 1. Each depositor makes a savings decision with a bank.

\footnotetext{
${ }^{8}$ Note that unlike the Diamond and Dybvig model, which has a positive and deterministic return, in our model the return is stochastic, with an expected positive value. Bank capital $K$ in our model provides provisional funds for depositors in case the return from a bank's investment is below the ex ante expectation.
} 


\section{William Davidson Institute Working Paper 444}

- Date 1: The entrepreneur learns the type of the project, and may stop the project in the case of a bad project. In such a case the entrepreneur gets a private benefit $b_{1}>0$ and all the banks observe the liquidation of the project. However, unless a project is stopped by the entrepreneur the bank(s) still does (do) not know the type of the project and further $I_{2}$ units of money are invested. Moreover, the bank(s) will know the probability of the distribution of their own projects better than other banks. Early consumers withdraw money from the banks, late consumers make decisions whether to withdraw or to keep deposits in the banks. A bank facing excessive early withdrawals has to decide whether to borrow from the interbank market or to face a bank run.

- Date 2: The type of a project becomes public knowledge:

- If a project is of a good type, a further $I_{3}$ will be invested.

- If it is a bad project, a decision whether to liquidate or to reorganize has to be made.

* If a project is liquidated the bank(s) gets zero and the entrepreneur gets $b_{2 b}<b_{1}$; otherwise,

$*$ if a project is reorganized, $I_{3}$ will be invested.

- After investing $I_{3}$, signals $s_{A}$ and $s_{B}$ are observed by the investor(s) and a reorganization strategy is chosen based on the signals.

- Date 3: All projects are completed,

- for a good project, return $Y$ goes to the bank(s), the entrepreneur gets $b_{3 b}>b_{1}$

- for a bad project, return $X$ goes to the bank(s), the entrepreneur gets $b_{3 g}>b_{3 b}$;

- late consumers collect their rewards. 


\section{William Davidson Institute Working Paper 444}

\subsection{Financial Institutions and Information Distributions}

In this section we explain how financial institutions can cause informational problems in an interbank market. In particular, why is there a severe information asymmetry among banks trading in the interbank market if every project is financed by a single bank alone, but the informational problem is not serious if every project is jointly financed by two or more banks? For more detailed technical results and their proofs, see Huang and Xu (1999).

Under single-bank financing, given that the earlier investments are sunk, the bank will choose an ex-post efficient strategy to reorganize the project such that the payoff is greater than the ex-post cost of refinancing, $I_{3}$. As a result, the bank is unable to commit to terminating a bad project ex post.

Moreover, the fact that the bank is not able to commit to terminating a bad project affects the entrepreneur's ex-ante incentives to reveal information. When the entrepreneur at date 1 discovers that his project is a bad one, he anticipates that the project will still be continued and refinanced by the bank at date 2 as long as it lasts until then. Consequently, if he decides to quit the project, he gets private benefit $b_{1}$; if he decides to continue the project, the bad project will always be refinanced by the bank and will generate a private benefit $b_{3 b}>b_{1}$ to the entrepreneur. Therefore, the entrepreneur will always choose to continue a bad project after he privately discovers its type. This implies that in an economy where every project is financed by one bank, the information to separate the good projects from the bad projects is available neither to the financier nor to the interbank market at date 1.

However, in the case of multi-bank financing, the asymmetric information and conflicts of interest among the co-financiers related to reorganizing the project incur a cost, $F$, for ex-post negotiations. When this cost, $F$, is high, the gain from reorganization is less than the total costs, i.e., $X<I_{3}+F$. Therefore reorganization is not worthwhile and liquidation will follow. ${ }^{9}$

\footnotetext{
${ }^{9}$ This is a reduced form of Huang and $\mathrm{Xu}$ (1999). It can also be derived from a variation of some
} 


\section{William Davidson Institute Working Paper 444}

The commitment to liquidate a bad project at date 2 has a deterrent effect on an entrepreneur who has a bad project. Fearing further losses of his private benefit later, an entrepreneur will choose to quit a bad project as soon as he discovers it is bad. Assuming the observability of liquidation, this result implies that if all projects in an economy are financed by two banks, at date 1 information is available in the interbank market to separate the good projects from the bad projects.

The following lemma summarizes the above results.

Lemma 1 At date 1, single-bank financing leads to a pooling equilibrium in the interbank market such that good projects cannot be distinguished from bad projects; multi-bank financing leads to a separating equilibrium in the interbank market such that good projects can be distinguished from bad projects.

To simplify our language in the above lemma, in the reminder of the paper we call an economy under multi-bank financing an economy with hard-budget constraints (HBC) and an economy under single-bank financing an economy with soft-budget constraints (SBC), terms coined by Kornai (1980).

\section{FINANCIAL CONTAGION AND FINANCIAL CRISES}

To present our basic point in the simplest possible way, we abstract government away from our model in this section. We will briefly discuss the role of government in the concluding remarks.

\subsection{Deposit Contract}

In our model a market equilibrium in which all agents trade can Pareto dominate that of autarchy; but the market equilibrium may or may not provide insurance against liquidity shocks. The main reason of interbank market failure in our model

other models, such as Dewatripont and Maskin (1995), Hart and Moore (1995), and Bolton and Scharfstein (1996). 


\section{William Davidson Institute Working Paper 444}

is that there may be information asymmetry which can give rise to contagious risks.

At date 0 , consumers make a deposit decision by solving

$$
\begin{aligned}
\max _{\left(C_{1}, C_{2}\right)} U & =\pi_{1} u\left(C_{1}\right)+\rho \pi_{2} u\left(C_{2}\right) \\
\text { s.t. } 1 & =\pi_{1} C_{1}+\pi_{2} C_{2} /(1+R)
\end{aligned}
$$

An ex-ante optimal market equilibrium can only be achieved by increasing $C_{1}$ and decreasing $C_{2}$. That is, $C_{1}^{*}>1$ and $C_{2}^{*}<1+R$.

A bank can implement a market solution through a deposit contract à la Diamond and Dybvig. That is, for $\$ 1$ deposit at $t=0$, a depositor receives either $C_{1}^{*}$ at $t=1$, or $C_{2}^{*}$ at the end of the exercise. For each dollar it receives as deposit, the bank holds $\pi_{1} C_{1}^{*}$ (as cash) at no extra cost, and invests the rest in illiquid technology which yields a higher return. As banks are competitive in the economy, at $C_{1}^{*}$ and $C_{2}^{*}$ banks on average earn zero profit. That is

$$
\pi_{1} C_{1}^{*}+\left(1-\pi_{1}\right) C_{2}^{*} /(1+R)=1
$$

and after paying off $C_{1}^{*}$ and $C_{2}^{*}$, the banks' capital still remains at $K$. This ex-ante optimal deposit contract is a pure strategy Nash equilibrium. That is, an early consumer always wants to consume at $t=1$, but a late consumer has no incentive to withdraw early. This is because as long as $\rho(1+R)>1, u^{\prime}\left(C_{1}^{*}\right)=\rho(1+R) u^{\prime}\left(C_{2}^{*}\right)$ holds if $C_{1}^{*}<C_{2}^{*}$, and any deviation does not pay, as long as other late consumers do not deviate.

However, when there is no interbank market, there may be a Diamond-Dybvig bank run equilibrium, that is, a simultaneous deviation of all late consumers from the efficient equilibrium. In this case, the bank has to liquidate its project (which for simplicity has zero value) if borrowing from the interbank market is not possible or too expensive. ${ }^{10}$ As a result, the bank will fail and nothing will be left for late consumers

\footnotetext{
${ }^{10}$ In a separate paper (Huang and $\mathrm{Xu}, 2001$ ) we allow banks to liquidate illiquid assets to solve their liquidity shortage problems. See Diamond and Rajan (1998) for an analysis of liquidating illiquid assets.
} 


\section{William Davidson Institute Working Paper 444}

when they withdraw later than others. Anticipating this, all late consumers will withdraw at $t=1$, and a bank run becomes self fulfilling.

In an economy with an interbank market, an illiquid bank may be able to borrow from the market such that the Diamond-Dybvig bank-run equilibrium can be eliminated all together. A key for the existence of a bank-run equilibrium is the possibility that a bank cannot solve its liquidity shortage problem by borrowing from the interbank market. This turns out to be a critical condition to retain bank-run equilibrium when one moves from a one-bank economy to a multi-bank economy.

In our multi-bank economy the total number of depositors is finite, with $N$ depositors in each bank, and the realized numbers of type 1 and 2 depositors for each bank are random draws from binomial distributions of $\pi_{1}$ and $\pi_{2}=1-\pi_{1}$ respectively. In the next two subsections, we will analyze financial contagion in MBF and SBF economies. We start with the problem faced by the bank manager in a MBF economy.

\subsection{Bank Run in a MBF Economy}

Following our results for a MBF economy, at equilibrium all bad projects are liquidated at date 1 , which is observable by all banks in the interbank market, and only good projects are continued. The ex-ante expected deposit return in such an economy is:

$$
R^{M}=\frac{\lambda Y-\left[I_{1}+\lambda_{o}\left(I_{2}+I_{3}\right)\right]}{I_{1}+\lambda_{o}\left(I_{2}+I_{3}\right)}>0 .
$$

To meet an expected number of early withdrawals a bank's optimal investment decision is to store cash in the amount of $N \pi_{1} C_{1}^{*}$, and to invest all the rest - in the amount of $N\left(1-\pi_{1} C_{1}^{*}\right)$ - into a project. Every bank co-invests with another bank in one project; given the symmetry of the banks, the investment is made in the following way,

$$
N\left(1-\pi_{1} C_{1}^{*}\right)=\frac{1}{2}\left[I_{1}+\lambda_{o}\left(I_{2}+I_{3}\right)\right]
$$

In the event that a project is a bad one and aborted at date 1 , the realized value 


\section{William Davidson Institute Working Paper 444}

from the investment is zero. In this case, if there are more than $\pi_{1} N+\frac{\lambda_{o}\left(I_{2}+I_{3}\right)}{C_{1}^{*}}$ depositors trying to withdraw at date 1, the bank will run out of cash because of the excessive demand for withdrawals. Because it is known that this bank has a bad project and will not be able to pay back its loan, no other bank will be willing to lend to it. Thus a bank run can occur in a MBF economy, when a bank is hit by both technological shocks and liquidity shocks. ${ }^{11}$

Now let us look at the case where a bank has a good project. Following our results for a MBF, at equilibrium only good projects are continued at date one. Thus it is a public knowledge in the interbank market that a bank is continuing a good project and this will definitely generate a return of

$$
R_{g}^{M}=\frac{Y-\left(I_{1}+I_{2}+I_{3}\right)}{I_{1}+I_{2}+I_{3}}>R^{M}
$$

In this case, when such a bank faces excess early withdrawals, it will have no difficulties in borrowing from other banks. ${ }^{12}$ Therefore, a bank with a good project can solve its liquidity shortage problem by borrowing from other banks and a bank run

\footnotetext{
${ }^{11}$ If late consumers can observe the liquidation of bad projects, it is certain that a bank run will occur after the bank's project is liquidated.

For the sake of simplicity, we do not allow the bank with a bad project to start another project at date 1. Moreover, this setup avoids giving a MBF economy too great of an advantage over a SBF economy, which would also divert the focus in our analysis.

${ }^{12}$ The bank can issue a risk-free bond to borrow from other banks. The bond has a face value of $\$ 1$ and is sold at price $p$ per share. $p$ is determined by the competitive bank lending market. At equilibrium $R_{g}^{H} \geq 1 / p$ and there is sufficient demand for such a bond.

From the supply side, since each bank stores $N \pi_{1} C_{1}^{*}$ amount of cash, there is enough supply of liquidity to meet the total amount of withdrawals of $M N \pi_{1} C_{1}^{*}$ as long as there is no bank run. Moreover, as some banks will have excess liquidity generated from the termination of bad projects, the liquidity supply in the interbank market is adequate. Indeed, banks can improve their ex ante liquidity management because of the excess liquidity available due to the termination of bad projects. Huang and $\mathrm{Xu}$ (2001) provide further analysis of the liquidity management of banks and of liquidity equilibrium in an interbank market.

Furthermore, because $C_{1}^{*}<C_{2}^{*}$, it is not worthwhile for any late consumers to withdraw deposits earlier (at date 1).
} 


\section{William Davidson Institute Working Paper 444}

is avoided.

Proposition 1 In a MBF economy, with symmetric information among banks, a bank run only occurs when a bank faces both technological and liquidity shocks, but a bank-run contagion is not possible.

The last point in the above proposition is more interesting. A MBF economy does not experience a contagious bank run simply because with symmetric information among banks, the interbank lending market is able to provide liquidity to all illiquid but solvent banks, i.e., the banks that are not hit by technological shocks. As a result, although there are still possible isolated bank runs in a MBF economy, a bank-run contagion does not occur.

\subsection{Bank Run in a SBF Economy}

Following the result of Lemma 1, in a SBF economy at date 1 there is a pooling equilibrium in the interbank market such that good projects cannot be distinguished from bad projects. Although no information about the projects is revealed in the market, we assume that after one period of financing and project monitoring, every bank has a better understanding of the probability distribution of its own project. That is, at date 1 , the manager of bank $m(m=1, \ldots, M)$ has better information than at date 0 , such that she knows that the probability of her project is a good one is $\lambda_{m}$. But this is her private information. Suppose that the qualities of all banks can be ranked as $\lambda_{1}<\lambda_{2}<\lambda_{3}<\ldots<\lambda_{M}$, which is not known by any bank manager,

but the average quality of banks, $\bar{\lambda}=\frac{1}{M} \sum_{m=1}^{M} \lambda_{m}$, is known to all banks; moreover, $\bar{\lambda}=\lambda_{o}$, the prior knowledge of the project quality, based on which the ex ante deposit contract is written. We assume that $K>0$ is enough to provide sufficient provisional funds even for the bank with the lowest quality $\lambda_{1}>0$.

Given that all projects are to be completed regardless of their quality in a SBF 


\section{William Davidson Institute Working Paper 444}

economy, the ex-ante expected deposit return in such an economy is:

$$
R^{S}=\frac{\lambda_{o} Y+\left(1-\lambda_{o}\right) X}{I}-1>0 .
$$

Obviously we have $R^{S}<R^{M}$.

Anticipating the expected number of early consumers' withdrawals at date 1 , a bank's optimal investment decision is to hold $N \pi_{1} C_{1}^{*}$ in cash and invest $N\left(1-\pi_{1} C_{1}^{*}\right)$. That is, the expected investment of a bank is $N\left(1-\pi_{1} C_{1}^{*}\right)=I$. Thus,

$$
C_{1}^{*}=\frac{N-I}{N \pi_{1}}
$$

Substituting $N=N \pi_{1} C_{1}^{*}+N\left(1-\pi_{1}\right) C_{2}^{*} /(1+R)$ in the above condition, we have

$$
C_{2}^{*}=\frac{\lambda_{o} Y+\left(1-\lambda_{o}\right) X}{N\left(1-\pi_{1}\right)} .
$$

Here, $\left(C_{1}^{*}, C_{2}^{*}\right)$ are the date 0 contract between a bank and its depositors.

Therefore, if the number of depositors who withdraw at date 1 is no more than the expected number $\pi_{1} N$, the bank will have enough cash to handle the withdrawals; if the number of early withdrawals is more than $\pi_{1} N$, however, the bank will have to borrow from the interbank market to meet the depositors' demands. We suppose illiquid banks will borrow by issuing bonds.

We assume that a borrower has limited liability. That is, an illiquid borrowing bank repays its borrowing only when it ends up with a good project. However, given that the market knows only $\bar{\lambda}$, all illiquid banks will be treated in the same way when they borrow. Therefore, all bonds issued by borrowing banks have the following structure: contingent on the realization of the project at date 3 , the bond pays,

$$
\begin{cases}1, & \text { if the project is good, } \\ 0, & \text { otherwise. }\end{cases}
$$

To highlight our points, we assume that there is a Bertrand competition among all lending banks such that these banks break even in lending. Hence, given the lenders' belief that the probability that a bank will pay back 1 is $\bar{\lambda}$, the equilibrium bond price is $p^{S}=\bar{\lambda}$. 


\section{William Davidson Institute Working Paper 444}

For an illiquid bank to deal with $n$ excessive early withdrawal consumers for an amount of $n C_{1}^{*}$, a total of $\frac{n C_{1}^{*}}{\lambda}$ shares of bonds should be issued. While the bond structure and expected payoff is the same for all lenders, with the private information about the quality of each bank's project, the borrowing cost for each bank is different. For bank $m$, with a probability of being able to repay the bond as $\lambda_{m}$, the expected cost of raising liquidity to deal with $n$ excessive early withdrawals is $\lambda_{m} \frac{n C_{1}^{*}}{\bar{\lambda}}$. Therefore, the higher the quality of a bank, or the higher the ratio $\frac{\lambda_{m}}{\bar{\lambda}}$, the higher the borrowing cost for bank $m$. Not surprisingly, only when the ratio $\frac{\lambda_{m}}{\lambda}$ is not too high and $\bar{\lambda}$ is not too low the expected profit of illiquid bank $m$ is non negative when it solves its liquidity problem through borrowing. Noting that $C_{2}^{*} / C_{1}^{*}=\frac{\pi_{1}}{1-\pi_{1}} \frac{\lambda_{o} Y+\left(1-\lambda_{o}\right) X}{N-I}$, we have the following results.

Lemma 2 With borrowing in the interbank market,

1. a moderate bank with $1 \leq \frac{\lambda_{m}}{\bar{\lambda}} \leq C_{2}^{*} / C_{1}^{*}$ maintains a non-negative profit after borrowing from the interbank market to meet excess early withdrawals;

2. a bad bank with $\frac{\lambda_{m}}{\bar{\lambda}}<1$ maintains a non-negative profit after borrowing from the interbank market to meet excess early withdrawals if the number of excess withdrawals is not too small such that $n>\widehat{n}_{m}$, which is defined in the proof; and

3. a good bank with $\frac{\lambda_{m}}{\lambda}>C_{2}^{*} / C_{1}^{*}$ maintains a non-negative profit if the total number of excess withdrawals $n_{m}$ is small enough such that $n_{m}<\bar{n}_{m}$, which is defined in the proof.

Proof. A bank's non-negative expected return condition is

$$
E(\Re)=K+\left(1-\lambda_{m}\right) X+\lambda_{m} Y-\left[\left(1-\pi_{1}\right) N-n\right] C_{2}^{*}-\lambda_{m} \frac{n C_{1}^{*}}{\bar{\lambda}} \geq K
$$

In the following we look at three different cases. 


\section{William Davidson Institute Working Paper 444}

First, if $1 \leq \frac{\lambda_{m}}{\bar{\lambda}} \leq C_{2}^{*} / C_{1}^{*}=\frac{\pi_{1}}{1-\pi_{1}} \frac{\lambda_{o} Y+\left(1-\lambda_{o}\right) X}{N-I}$, we have $n\left(C_{2}^{*}-\frac{\lambda_{m}}{\bar{\lambda}} C_{1}^{*}\right) \geq 0$ for any $n>0$. Then $E(\Re)>K$ always holds because

$$
\left(1-\lambda_{m}\right) X+\lambda_{m} Y-\left(1-\pi_{1}\right) N C_{2}^{*} \geq 0
$$

holds for $\lambda_{m} \geq \bar{\lambda}$.

Second, if $\frac{\lambda_{m}}{\bar{\lambda}}<1$, we have $n\left(C_{2}^{*}-\frac{\lambda_{m}}{\bar{\lambda}} C_{1}^{*}\right)>0$, but

$$
\left(1-\lambda_{m}\right) X+\lambda_{m} Y-\left(1-\pi_{1}\right) N C_{2}^{*}=\left(\lambda_{m}-\bar{\lambda}\right)(Y-X)<0,
$$

because $\lambda_{m}<\bar{\lambda}$. Thus $E(\Re) \geq K$ holds if

$$
n_{m}\left(C_{2}^{*}-\frac{\lambda_{m}}{\bar{\lambda}} C_{1}^{*}\right)>\left(\bar{\lambda}-\lambda_{m}\right)(Y-X) .
$$

That is,

$$
n_{m}>\widehat{n}_{m} \equiv \frac{\left(\bar{\lambda}-\lambda_{m}\right)(Y-X)}{\left(C_{2}^{*}-\frac{\lambda_{m}}{\bar{\lambda}} C_{1}^{*}\right)}=\frac{\left(\bar{\lambda}-\lambda_{m}\right) \pi_{1}\left(1-\pi_{1}\right) N(Y-X)}{\pi_{1}\left[\lambda_{o} Y+\left(1-\lambda_{o}\right) X\right]-\frac{\lambda_{m}}{\bar{\lambda}}\left(1-\pi_{1}\right)(N-I)}
$$

Finally, if $\frac{\lambda_{m}}{\bar{\lambda}}>C_{2}^{*} / C_{1}^{*}, E(\Re)>K$ if and only if

$$
\left(1-\lambda_{m}\right) X+\lambda_{m} Y-\left(1-\pi_{1}\right) N C_{2}^{*}=\left(\lambda_{m}-\bar{\lambda}\right)(Y-X)>n_{m}\left[\frac{\lambda_{m}}{\bar{\lambda}} C_{1}^{*}-C_{2}^{*}\right] .
$$

That is,

$$
n_{m}<\bar{n}_{m} \equiv \frac{\left(\lambda_{m}-\bar{\lambda}\right) \pi_{1}\left(1-\pi_{1}\right) N(Y-X)}{\frac{\lambda_{m}}{\bar{\lambda}}\left(1-\pi_{1}\right)(N-I)-\pi_{1}\left[\lambda_{o} Y+\left(1-\lambda_{o}\right) X\right]}
$$

The intuition behind this lemma is clear. In a lemon interbank market, a good bank with $\lambda_{m}>\bar{\lambda}$ borrowing is equivalent to providing subsidies to bad banks with $\lambda_{m} \leq \bar{\lambda}$; and the better a bank is the more subsidies it provides. In the first case, for a moderate bank the project is good enough to have a positive expected net return and the subsidy provided to others is not much, thus borrowing from the interbank market will not be a problem. In the second case, a bad bank benefits not only because it receives subsidies through borrowing from the interbank market but also it substitutes date 3 payment $C_{2}^{*}$ by a low date 1 payment $C_{1}^{*}$ to depositors. 


\section{William Davidson Institute Working Paper 444}

Thus, when the number of early withdrawals is large enough, $n_{m}>\widehat{n}_{m}$, a bad bank will be able to make an expected positive payoff by borrowing. However, in the last case, for a good bank only when the number of early withdrawals is not too large, i.e. $n_{m}<\bar{n}_{m}$, the need to borrow is low and the costs of subsiding others will be affordable such that the expected payoff is not negative.

Notice that if $\lambda_{m}$ refers to the best bank, the ratio $\frac{\lambda_{m}}{\lambda_{o}}$, a measure of the heterogeneity of the project pool in the economy, can also be interpreted as a measure of the degree of information asymmetry in the interbank market. A perfectly homogeneous case is one where for every bank $m, \lambda_{m}=\lambda_{o}=\bar{\lambda}$. Applying Lemma 2, when the banks in the economy are perfectly homogeneous, every bank in the economy satisfies the condition $1 \leq \frac{\lambda_{m}}{\bar{\lambda}}<C_{2}^{*} / C_{1}^{*}$ so that it maintains a non-negative profit after borrowing to meet excess early withdrawals.

Corollary 1 If $\lambda_{m}=\bar{\lambda}=\lambda_{o}$, then every bank is willing to borrow from the interbank market to meet excess early withdrawals and there is no bank run at equilibrium.

In the following we have comparative static results about $\bar{n}_{m}$ and $\widehat{n}_{m}$.

Lemma $3 \partial \bar{n}_{m} / \partial \lambda_{m}<0$ but $\partial \bar{n}_{m} / \partial \bar{\lambda}>0 ; \partial \widehat{n}_{m} / \partial \lambda_{m}<0$ but $\partial \widehat{n}_{m} / \partial \bar{\lambda}>0$.

Proof. Because $C_{1}^{*}-C_{2}^{*}<0$, that is

$$
\left(1-\pi_{1}\right)(N-I)-\pi_{1}\left[\lambda_{o} Y+\left(1-\lambda_{o}\right) X\right]<0,
$$

we have

$$
\begin{aligned}
\frac{\partial \bar{n}_{m}}{\partial \lambda_{m}} & =\frac{\partial}{\partial \lambda_{m}} \frac{\left(\lambda_{m}-\bar{\lambda}\right) \pi_{1}\left(1-\pi_{1}\right) N(Y-X)}{\frac{\lambda_{m}}{\bar{\lambda}}\left(1-\pi_{1}\right)(N-I)-\pi_{1}\left[\lambda_{o} Y+\left(1-\lambda_{o}\right) X\right]} \\
& =\frac{\left[\left(1-\pi_{1}\right)(N-I)-\pi_{1}\left[\lambda_{o} Y+\left(1-\lambda_{o}\right) X\right]\right]\left[\pi_{1}\left(1-\pi_{1}\right) N(Y-X)\right]}{\left[\frac{\lambda_{m}}{\lambda}\left(1-\pi_{1}\right)(N-I)-\pi_{1}\left[\lambda_{o} Y+\left(1-\lambda_{o}\right) X\right]\right]^{2}} \\
& <0,
\end{aligned}
$$

Moreover,

$$
\frac{\partial \bar{n}_{m}}{\partial \bar{\lambda}}=\frac{\partial}{\partial \bar{\lambda}} \frac{\left(\lambda_{m}-\bar{\lambda}\right) \pi_{1}\left(1-\pi_{1}\right) N(Y-X)}{\frac{\lambda_{m}}{\lambda}\left(1-\pi_{1}\right)(N-I)-\pi_{1}\left[\lambda_{o} Y+\left(1-\lambda_{o}\right) X\right]}
$$




\section{William Davidson Institute Working Paper 444}

$$
\begin{aligned}
& =\frac{\left[\left(\frac{\lambda_{m}}{\bar{\lambda}}\right)^{2}\left(1-\pi_{1}\right)(N-I)+\pi_{1}\left[\lambda_{o} Y+\left(1-\lambda_{o}\right) X\right]\right]\left[\pi_{1}\left(1-\pi_{1}\right) N(Y-X)\right]}{\left[\frac{\lambda_{m}}{\lambda}\left(1-\pi_{1}\right)(N-I)-\pi_{1}\left[\lambda_{o} Y+\left(1-\lambda_{o}\right) X\right]\right]^{2}} \\
& >0 .
\end{aligned}
$$

Similarly, we have

$$
\frac{\partial \widehat{n}_{m}}{\partial \lambda_{m}}<0<\frac{\partial \widehat{n}_{m}}{\partial \bar{\lambda}}
$$

because the algebraic expressions for $\widehat{n}_{m}$ and $\bar{n}_{m}$ are the same.

The intuition of the first result is the following. Better banks subsidize the borrowing of bad banks from the interbank market, moreover, the better the quality of the bank is and the more the bank borrows, the more subsidies it pays. As a result, everything being equal, the better a bank's quality, the smaller number of excess early withdrawals the bank is willing to deal with by borrowing. The second result implies that when the average quality of all borrowing banks is lower, the number of excess early withdrawals that a good bank is willing to deal with through borrowing declines. This result will be important when we analyze contagious risks in the interbank market.

It is interesting to note that mathematically comparative static expressions for bad banks are the same as those for good banks. But the interpretations should be as follows. The worse a bad bank is, the larger the number of excess early withdrawals it needs to make its expected payoff positive through borrowing. Moreover, the higher the average quality of illiquid banks, the larger the number of excess early withdrawals an illiquid bad bank will need.

In the following we will analyze a bank-run equilibrium in a SBF economy. To simplify analysis, we suppose that a bank manager has an incentive to avoid being identified as a poor manager. We also assume that a bank that loses its capital, and thus is unable to meet the capital adequacy requirement or is liquidated, is perceived as an indication of bad management; while a bank run is not perceived as such since a well-managed bank may also suffer from a bank run. Thus, from the perspective of a bank manager, the expectation of being unable to meet the capital adequacy 


\section{William Davidson Institute Working Paper 444}

requirement or of liquidating at date 3 is worse than a bank run at date 1 . Therefore, when a manager has to choose between facing an expected liquidation at date 3 and a bank run at date 1 , she will choose the latter. ${ }^{13}$ Given these assumptions applying the above Lemmas, given $C_{2}^{*} / C_{1}^{*}=\frac{\pi_{1}}{1-\pi_{1}} \frac{\lambda_{o} Y+\left(1-\lambda_{o}\right) X}{N-I}$, we have the following results.

Proposition 2 In a SBF economy

1. if banks' projects are perfectly homogeneous, then bank runs never occur;

2. if banks' projects are heterogeneous, then for any bank $m$

- if $\lambda_{m}<\bar{\lambda}$ and $n_{m}<\widehat{n}_{m}$, this bank will suffer from a bank run;

- if $\lambda_{m} \in\left[\bar{\lambda}, \bar{\lambda} C_{2}^{*} / C_{1}^{*}\right]$, borrowing from the interbank market is always desirable;

- if $\lambda_{m}>\bar{\lambda} C_{2}^{*} / C_{1}^{*}$ and $n_{m}>\bar{n}_{m}$, this bank will suffer from a bank run.

The intuition of the former is straightforward. When projects are perfectly homogeneous there is no information asymmetry in the interbank market even in a SBF economy. If that is the case and the uncertainty of projects financed by banks is reasonably low, the interbank market will function well and there is no bank run in a $\mathrm{SBF}$ economy. In contrast, as long as projects are heterogeneous in a MBF economy illiquid and insolvent banks may still suffer bank runs even when the project pool is relatively safe. That is, if one ignores heterogeneity of projects in economies, a SBF economy may appear better than a MBF economy in terms of financial stability when the project pool of the banks in the economy is less uncertain. This result sheds some light on the 'East Asian miracle' which occurred before the mid 1990s when the project pool in those economies featured less uncertain imitations.

The latter results for heterogenous projects show that a bad and illiquid bank welcomes a large amount of excess withdrawals, which gives the bank a chance to become solvent due to the implicit subsidy through borrowing. However, the interbank

\footnotetext{
${ }^{13}$ The same qualitative result can be derived without this assumption but at the cost of a more complicated analysis.
} 


\section{William Davidson Institute Working Paper 444}

market will function well for banks with moderate quality projects regardless of the number of early withdrawals. This is because these banks provide few subsidies to others through borrowing. Finally, when the number of excess withdrawals is larger than a critical level, good and illiquid banks will be run by their depositors. This is because their subsidies to bad banks are so high that they become insolvent when

they borrow too much. To avoid the consequence of liquidation these bank managers choose not to borrow. The implication of this result is harmful to the economy due to the negative externalities of runs of good banks in the interbank market.

\subsection{Bank-Run Contagion and Financial Crisis in a SBF Economy}

Our analysis in the above subsection has shown that under some conditions although a interbank market in a SBF economy is a lemon market, it still functions for banks to share liquidity risks. However, when those conditions are not satisfied, the results can be serious. In this subsection, we analyze contagious risks in the interbank market. In particular, we show that if bank runs occur to good quality banks, this can lead to contagious massive bank failures, which can lead to a financial crisis.

The insights from Proposition 2 above reveal several interesting cases. First, if the quality of the bank portfolio is close to perfectly homogeneous and the average quality is not too low, then there is no bank-run contagion.

Second, if the bank portfolio quality is heterogeneous but only a small number of excess withdrawals occur from good banks, then the interbank market should function well and there will be no bank run.

Third, if the bank portfolio quality is heterogeneous but a large number of excess withdrawals only occur to bad banks, there will be isolated bank runs from bad banks only. This happens when the number of excess early withdrawals is related the portfolio quality of the bank. That is, bank runs are information-based as in Postlewaite and Vives (1987) and Jacklin and Bhattacharya (1988), who suggest that depositors can have imperfect monitoring of bank assets. 


\section{William Davidson Institute Working Paper 444}

Fourth, if the bank portfolio quality is heterogeneous and there are some large excess early withdrawals $\left(n_{m}>\bar{n}_{m}\right)$ from good banks and yet an insufficient number of early withdrawals from bad banks, the banking system may also be subject to a contagious bank run. ${ }^{14}$ The insight from this case can be seen more clearly as our analysis proceeds.

For simplicity, we assume that the liquidity shock is exogenously given such that there are $w$ illiquid good, moderate, and bad banks that face the same amount, $\widehat{n}$, of excess early withdrawals. The average quality of all illiquid banks is

$$
\bar{\lambda}_{w}=\frac{1}{w} \sum_{i=1}^{w} \lambda_{i}
$$

We also continue to assume that the average quality $\bar{\lambda}_{w}$ is known by all banks, but each individual bank's $\lambda_{i}$ is not known by other banks.

To facilitate our analysis, we group the $w$ banks into three partitions, good $\left(W_{g}\right)$, ugly $\left(W_{u}\right)$, and bad $\left(W_{b}\right)$, such that $\lambda_{w_{b}+1}=\bar{\lambda}_{w}$, and $\lambda_{w_{u}}=\bar{\lambda}_{w} \frac{C_{2}^{*}}{C_{1}^{*}}$. The relationship between the ranking of the banks and the partition is illustrated in the following.

$$
\underbrace{\lambda_{1}<\lambda_{2}<\ldots<\lambda_{w_{b}}}_{W_{b}: \widehat{n}_{w_{b}}>\widehat{n}}<\underbrace{\lambda_{w_{b}+1}<\ldots \ldots<\lambda_{w_{u}}}_{W_{u}}<\underbrace{\lambda_{w_{g}}<\hat{n}}_{W_{g}: \bar{n}_{w_{g}}}
$$

Obviously, in partition $W_{b}$, a bank has a subscript $i$ that $1 \leq i \leq w_{b}$ and $\lambda_{w_{b}}<\bar{\lambda}_{w}$; while in partition $W_{u}$, a bank has a subscript $i$ that $1+w_{b} \leq i \leq w_{u}, \lambda_{w_{b}+1} \geq \bar{\lambda}_{w}$ and $\lambda_{w_{u}} \leq\left(C_{2}^{*} / C_{1}^{*}\right) \bar{\lambda}_{w}$; finally, in partition $W_{g}$, a bank has a subscript $i$ that $w_{g}<i \leq w$, where $w_{g}=w_{u}+1$, and $\lambda_{w_{u}+1}>\left(C_{2}^{*} / C_{1}^{*}\right) \bar{\lambda}_{w}$.

Depending on the magnitude of exogenous shock $\widehat{n}$ there are three possible cases: case one $-\widehat{n}>\widehat{n}_{w_{b}}>\bar{n}_{w_{g}} ;$ case two $-\widehat{n}_{w_{b}}>\widehat{n}>\bar{n}_{w_{g}} ;$ and case three $-\widehat{n}_{w_{b}}>\bar{n}_{w_{g}}>\widehat{n}$, where $\widehat{n}_{w_{b}}=\widehat{n}\left(\lambda_{w_{b}}\right)$ and $\bar{n}_{w_{g}}=\bar{n}\left(\lambda_{w_{g}}\right)$ are determined by applications of Lemma 2 .

Let us start with the first case of $\widehat{n}>\widehat{n}_{w_{b}}>\bar{n}_{w_{g}}$.

Given $\partial \bar{n}_{i} / \partial \lambda_{i}<0$ (Lemma 3 ) and $\widehat{n}>\bar{n}_{w_{g}}$, applying Proposition 2 all banks in the $W_{g}$ partition decide not to borrow from the interbank market and suffer from

\footnotetext{
${ }^{14}$ This can happen either when depositors' monitoring is more blurred than that of the bank managers' or when depositors at a good quality bank face a stronger liquidity shock than others.
} 


\section{William Davidson Institute Working Paper 444}

bank runs. Applying the same proposition, banks in the $W_{u}$ and $W_{b}$ partitions would choose to borrow in the interbank market to deal with the excessive early withdrawals.

However, the decision of the $W_{g}$ banks not to borrow generates externalities in the interbank market so that the average quality of borrowing banks is lowered. The average quality of the remaining illiquid banks to borrow from the interbank market, $\bar{\lambda}_{w_{u}}$, will decrease to

$$
\bar{\lambda}_{w_{u}}=\frac{1}{w_{u}} \sum_{i=1}^{w_{u}} \lambda_{i}<\bar{\lambda}_{w}
$$

This also lowers the critical value $\left(C_{2}^{*} / C_{1}^{*}\right) \bar{\lambda}_{w_{u}}$.

With a lowered $\bar{\lambda}_{w_{u}}$, some better $W_{u}$ banks may have higher $\lambda$ than the new threshold value $\left(C_{2}^{*} / C_{1}^{*}\right) \bar{\lambda}_{w_{u}}$; similarly, some less bad $W_{b}$ banks may become better than the new average $\bar{\lambda}_{w_{u}}$. Under the lowered average quality, the partition of the remaining borrowing-banks in the interbank market is the following: for partition $W_{b b}, \lambda_{w_{b b}}<\bar{\lambda}_{w_{u}}$; for partition $W_{u b}, \lambda_{b_{b}+1} \geq \bar{\lambda}_{w_{u}}$ and $\lambda_{w_{u b}} \leq\left(C_{2}^{*} / C_{1}^{*}\right) \bar{\lambda}_{w_{u}}$; finally, for partition $W_{u g}, \lambda_{w_{u b}+1}>\left(C_{2}^{*} / C_{1}^{*}\right) \bar{\lambda}_{w_{u}}$ The partitions are illustrated as follows.

$$
\underbrace{\lambda_{1}<\lambda_{2}<\ldots<\lambda_{w_{b b}}}_{W_{b b}}<\underbrace{\lambda_{w_{b b}+1}<\ldots \ldots<\lambda_{w_{u b}}}_{W_{u b}}<\underbrace{\lambda_{w_{u b}+1}<\ldots \ldots<\lambda_{w_{u}}}_{W_{u g}}
$$

Applying Lemma 3 , with a lowered $\bar{\lambda}_{w_{u}}, \bar{n}_{w_{u g}}$ and $\widehat{n}_{w_{b b}}$ are also lowered so that the condition $\widehat{n}>\widehat{n}_{w_{b b}}>\bar{n}_{w_{u g}}$ is satisfied. Given these conditions, the logic repeats that $W_{u g}$ banks decide not to borrow and thus they encounter bank runs. As a result, the average quality of the remaining illiquid banks, the banks in partitions $W_{b b}$ and $W_{u b}$, will be further lowered. This in turn will further increase the borrowing cost. The same process repeats such that there will be additional bank runs, further deterioration of the quality of banks, and a further lowering of bond prices until they reach such a low level that no bank is willing to borrow at the interbank market rate. We regard this result as a bank-run contagion or financial crisis.

Now we analyze the second case where $\widehat{n}_{w_{b}}>\widehat{n}>\bar{n}_{w_{g}}$. In this case, the behavior of banks in partitions $W_{g}$ and $W_{u}$ are the same as in the first case. However, the amount of excess early withdrawals faced by the banks in partition $W_{b}$ is not so large 


\section{William Davidson Institute Working Paper 444}

that after paying the early withdrawals through (implicitly subsidized) borrowing they still incur losses. Given the assumption that $\widehat{n}$ is the same for all the illiquid banks and $\bar{\lambda}_{w}$ is public knowledge, the bad banks will anticipate that the good illiquid banks may face bank runs. As a result, the number of early withdrawals may increase dramatically. With this expectation, banks in partition $W_{b}$ will choose to borrow in the interbank market so as to wait until there are a large enough number of early withdrawals to turn their losses into profits.

Following a similar analysis to case one, when banks in partition $W_{g}$ pull out from the interbank borrowing, the average quality of the borrowers interbank market deteriorates. This may cause some banks in partition $W_{u}$ also not to borrow while the worst banks in partition $W_{b}$ are still better off from borrowing. Repeating this logic, similar to case one, the economy may end up with a bank-run contagion and financial crisis.

Finally, we analyze the last case where the number of excessive early withdrawals is small, i.e., $\widehat{n}_{w_{b}}>\bar{n}_{w_{g}}>\widehat{n}$. In this case, all illiquid banks in partitions $W_{g}$ and $W_{u}$ will borrow in the interbank market to deal with the excessive early withdrawals. However, all banks in partition $W_{b}$ will not borrow and thus will encounter bank runs. But these are isolated bank runs, i.e., there is no contagion and no financial crisis.

The above three cases can be condensed into two cases: the case of $\widehat{n}>\widehat{n}_{w_{g}}$ and the case of $\widehat{n} \leq \widehat{n}_{w_{g}}$.

\section{Proposition 3 In a SBF economy,}

1. if the economy-wide bank portfolio quality is highly homogeneous and the average quality is not too low, there is no bank run;

2. if the economy-wide bank portfolio quality is highly heterogeneous and

- the number of excess withdrawals is large enough such that $\widehat{n}>\widehat{n}_{w_{g}}$, the banking system faces a contagious bank run; however, if 


\section{William Davidson Institute Working Paper 444}

- $\widehat{n} \leq \widehat{n}_{w_{g}}$, there only will be bank runs to bad banks and there will be no bank-run contagion.

These results shed light on the timing of the East Asian financial crisis, in particular, on why Korea was hit by the crisis and why the Japanese economy stagnated since the 1980s. In the early 1990s (the 1980s for Japan), the Korean economy became more developed, moving onto technological frontiers and investing more in high-tech projects and in innovations; its project pool became more uncertain and more heterogeneous. Thus the Korean economy began to meet the conditions for a bank-run contagion and could face a financial crisis if some liquidity shocks were to hit the economy. ${ }^{15}$

In sharp contrast, in a MBF economy information about bank investment quality is revealed to all banks at date 1 because of the liquidation of bad projects. As a result of the symmetric information, bank runs are always restricted to insolvent banks and the interbank market never degenerates. Therefore, a bank-run contagion will never occur when there are only idiosyncratic shocks!

\section{CONCLUDING REMARKS}

This paper endogenizes contagious risks and financial crises from the perspective of financial institutions and corporate finance. We began our analysis by examining informational problems not only between entrepreneurs and banks but also in the interbank market. Then we showed how in a SBF economy the information asymmetry between entrepreneurs and banks leads to a "lemon" problem in the interbank lending market, which further impedes strong banks from securing loans to solve liquidity shortage problems when they face liquidity shocks. Therefore, bank runs may break out, thus further exacerbating the lemon problem and possibly leading to a collapse of the entire banking system. In contrast, under a MBF economy entrepre-

\footnotetext{
${ }^{15}$ Radelet and Sachs (1998) provide detailed accounts of the "bank-run" contagion during the East Asian financial crisis.
} 


\section{William Davidson Institute Working Paper 444}

neurs reveal their private information to the banks in a timely fashion. As a result information about the quality of the banks is disclosed also to the whole banking system in a timely fashion. This allows the interbank lending markets to function well in providing loans to illiquid but solvent banks. Thus, solvent banks will be rescued and financial crisis will be avoided.

Our theory helps to reconcile the seemingly paradoxical phenomena between the "East Asian miracle" during the three decades prior to 1997 and the East Asian financial crisis in the period after 1997. During the period of early development, that is, the catching-up period of the 1960s to the early 1990s, the uncertainty of projects was low due to the nature of technological imitation. In this situation, our theory predicts that in a SBF economy there are no project liquidations and no bank runs. That is, a SBF economy appears even to outperform a MBF economy, and it may attract many investments. However, if the uncertainty of projects rises precipitously, for example, when an economy moves on to technological frontiers (e.g., South Korea since the early 1990s), the negative effects of a SBF economy will dominate, finally leading to trouble in the financial system.

Some final remarks about our theory are in order. Although our theory is motivated by observations of the East Asian financial crisis, it is a very basic model that aims to improve our general understanding of financial crises. In the real world, there may not exist a simple MBF economy such that all bad projects are liquidated as cleanly and early as in our model. That is, even in a well-developed market economy there exist some SBF financial and economic institutions which may cause bank runs or even financial crises, but to a lesser degree than in an economy where SBF predominates. However, the basic message of our theory is clear.

Moreover, in order to study financial crises from a purely economic perspective, we provide an institutional foundation for soft-budget constraints where there are no political problems and every agent maximizes his/her own economic gain. But our theory of financial crises is general enough that any institutional foundation for a soft-budget constraint economy (e.g., a foundation based on political considerations, 


\section{William Davidson Institute Working Paper 444}

Segal, 1998) applies and can produce the same qualitative results. For example, it is well documented that there is serious corruption in some of the Asian economies, and it is a widely held belief that corruption in those economies, particularly in the Philippines and Thailand, and probably also in Malaysia and even Korea, had an effect on their financial crises. Our model also allows us to examine how corruption affects financial institutions and changes the likelihood of financial crisis.

There are two aspects of corruption that can be introduced into our model. The first aspect is that corruption itself can be a mechanism of a soft-budget constraint (Shleifer and Vishny, 1993). That is, when it is discovered that a project is a bad one at date 2 , firms and financial institutions in a corrupt economy have the option of bribing the government to bailout the project, even if the project is not ex post profitable. That is, with corruption financial discipline will be less effective in the economy.

In addition, another aspect of corruption can also be incorporated into our model; that is, corruption can affect the selection of projects. This aspect will significantly alter our results regarding the timing of financial crisis. For illustrative purposes, we suppose that at date 0 there is asymmetric information such that entrepreneurs know the distribution better; moreover, some risky projects may benefit some entre-

preneurs. In a corrupt economy the entrepreneur may bribe the bank to get financing for the project. Thus, on average projects selected in a corrupt economy will be riskier than those in a corruption-free economy. Therefore, even in a less developed economy like the Philippines and Thailand, many high risk projects may be chosen because of corruption. As corruption not only taints financial discipline but also makes selection gear towards more risky projects, Proposition 3 implies that a corrupt economy is more likely to have a financial crisis.

Our theory has implications for many policy solutions proposed in the literature. For example, Dewatripont-Tirole (1994) propose the following policies to deal with bank failures: 1) to liquidate illiquid banks; 2) to allow solvent and liquid banks to take over illiquid banks; and 3) to provide loans to illiquid banks. Our theory 


\section{William Davidson Institute Working Paper 444}

demonstrates that in a MBF economy, with sufficient information about the solvency of illiquid banks, the government should consider the trade-off between closing down illiquid banks and letting solvent liquid banks take over illiquid banks; or to provide loans to solvent illiquid banks. However, in a SBF economy, without information about the solvency of the banks, the government has no other choice but to provide loans to all illiquid banks or to provide loans to a proportion of them randomly. With respect to nationalizing illiquid banks, our theory implies that this may work as an emergency measure if nationalization has an informational value such that with control rights the government may be able to identify the solvent banks. However, this may not work in the long run because a nationalized bank will likely generate a SBF environment.

Regarding the lender of last resort (LOLR) policy, ${ }^{16}$ since the government also faces an adverse selection problem in the sense that it does not know the solvency of each bank at date 1, an implication of our theory is that the best that the government can do may be either to rescue all the banks regardless of their solvency, thus creating a bail-out trap, or to rescue none of them, thus leaving the banking system vulnerable to contagious risks and financial crises. Therefore, focusing on the information asymmetry between the government and illiquid banks and effectively dealing with it is a key to the implementation of the LOLR policy.

Another important policy issue concerns the liberalization of financial markets and institutions, whose effects can be analyzed in our model by comparing a one bank economy (before liberalization) with an $M$-bank economy (after liberalization). According to our theory, a one-bank economy must be a SBF economy. Moreover, because all the deposits in the economy are pooled in one bank, the risk of facing a liquidity shock or a bank run will be greatly reduced. Theoretically, if the economy has a sufficiently large number of depositors, then the probability of excessive early withdrawals from the bank will be negligible. That is, although inefficient, this one-

\footnotetext{
${ }^{16}$ See Goodhart and Huang (1998) for a LOLR model and Huang and Xu (2000) for further discussions on contagious risks and LOLR policy.
} 


\section{William Davidson Institute Working Paper 444}

bank economy is almost immune to bank runs or financial crisis. In contrast to a one-bank economy, an $M$-bank SBF economy is very sensitive to a bank-run contagion due to the lemon problem in the interbank lending market.

This comparison has important implications for banking policies and reforms. The basic message is that a liberalization of financial institutions must be conditional on measures to harden the budget constraints. If liberalized banks are operating under a SBF and measures to harden the budget constraints are not in place, a liberalization policy may greatly destabilize the financial system!

This simple analysis captures some characteristics of banking reform and liberalization. For instance, a major reform measure in the transition from a centralized economy to a market economy is to change the banking system from a one-bank system (at least conceptually one can regard all state banks as branches of one bank - the state bank) into a multi-bank system. Many of the banking system liberalization reforms in East Asia before 1997 shared this spirit as well. According to our theory, a banking system reform designed to enhance competition as described above can create huge contagious risks to the system, if additional measures to harden the budget constraints in the system are not implemented simultaneously.

Another important policy implication from our theory for financial system reform and for financial-crisis prevention is that the transparency of the banking system is critical. However, transparency cannot be achieved by imposing government regulations alone. In fact, if the wrong issues of transparency are targeted, a regulation may backfire in the sense that the commitment device of the banks can be destroyed even in a MBF economy. This is because the commitment device relies on an information asymmetry between banks. Therefore, an effective reform can only be achieved by reforming the financial institutions to tighten the budget constraints at the micro level.

Finally, our work complements the existing literature on banking and financial crisis. This can be seen more clearly through by comparing our work with some of the existing literature. Allen and Gale (2000) in the Diamond and Dybvig one- 


\section{William Davidson Institute Working Paper 444}

bank framework show that bank runs are related to the business cycle, rather than being the results of simple "sunspots." We are in agreement with their view in that fundamentals affect financial crises, and we argue that financial institutions are just such a fundamental factor, especially in a multi-bank banking system. Chang and Velasco (2001) extend the Diamond and Dybvig model to an open economy model. They show that the illiquidity of the domestic financial system is at the center of a financial crisis in emerging markets. We regard the Chang and Velasco model as complementary to our theory. In fact, we can readily apply their approach to extend our model and explain how domestic financial institutions interact with international financial issues and how an over-borrowing syndrome in the sense of McKinnon and Pill (1997) is generated. 


\section{William Davidson Institute Working Paper 444}

\section{REFERENCES}

[1] Aghion, Philippe, Patrick Bolton, and Mathias Dewatripont (1999), "Contagious Bank Failures," mimeo, University College of London, Princeton University, and ECARE.

[2] Akerlof, George A. (1970), "The Market for Lemons: Quality Uncertainty and the Market Mechanism," Quarterly Journal of Economics, 89: 488-500.

[3] Allen, Franklin, and Douglas Gale (2000), "Financial Contagion," Journal of Political Economy, 108(1): 1-33.

[4] Aw, Bee Yan, Sukkyun Chung, and Mark J. Roberts (1998), "Productivity and the Decision to Export: Micro Evidence from Taiwan and South Korea," NBER Working Paper: 6558.

[5] Bhattacharya, Sudipto, and Douglad Gale (1987), "Preference Shocks, Liquidity, and Central Bank Policy," in W. Barnett and K. Singleton (eds.), New Approaches to Monetary Economics: Proceedings of the Second International Symposium in Economic Theory and Econometrics. New York and Melbourne: Cambridge University Press, pp. 69-88.

[6] Bhattacharya, Sudipto, and Anjan V. Thakor (1993), "Contemporary Banking Theory," Journal of Financial Intermediation, 3: 2-50.

[7] Bolton, Patrick, and David S. Scharfstein (1996), "Optimal Debt Structure and the Number of Creditors," Journal of Political Economy, 104(1): 1-25.

[8] Borensztein, Eduardo, and Jong-Wha Lee (1998), "Financial Distortions and Crisis in Korea," mimeo, IMF and Korea University.

[9] Chang, Roberto, and Andres Velasco (2001), "A Model of Financial Crises in Emerging Markets," Quarterly Journal of Economics, 116(2), May 2001, pages 489-517. 


\section{William Davidson Institute Working Paper 444}

[10] Cho, Yoon Je, and Joon-Kyung Kim (1995), "Credit Policies and the Industrialization of Korea," Discussion Paper 286, The World Bank.

[11] Dailami, Mansoor, and E. Han Kim (1994), "The Effect of Debt Subsidies on Corporate Investment Behavior," Pacific-Basin Finance Journal, March 1994.

[12] Demetriades, Panicos, and Bassam Fattouh (1998), "Unproductive Credit' and the South Korean Crisis," mimeo, South Bank University.

[13] Dewatripont, Mathias, and Eric Maskin (1995), "Credit and Efficiency in Centralized and Decentralized Economies," Review of Economic Studies, 62 (4): 541-55.

[14] Dewatripont, Mathias, and Jean Tirole (1994), The Prudential Regulation of Banks, Cambridge, Mass.: MIT Press.

[15] Diamond, Douglas (1984), "Financial Intermediation and Delegated Monitoring," Review of Economic Studies, 51(July): 393-414.

[16] Diamond, Douglas, and Phillip Dybvig (1983), "Bank Runs, Liquidity, and Deposit Insurance," Journal of Political Economy, 91:401-19.

[17] Diamond, Douglas, and Raghuram G. Rajan (1998), "Liquidity Risk, Liquidity Creation and Financial Fragility: A Theory of Banking," mimeo, Graduate School of Business, University of Chicago.

[18] Edison, Hali J., Pongsak Luangaram, and Marcus Miller (1998), "Asset Bubbles, Domino Effects and 'Lifeboats': Elements of the East Asian Crisis," CEPR Discussion Paper Series 1866.

[19] Goodhart, Charles A.E., and Haizhou Huang (1998), "A Model of the Lender of Last Resort," FMG Discussion Paper 313, London School of Economics.

[20] Gorton, Gary, and George Pennacchi (1990), "Financial Intermediaries and Liquidity Creation," Journal of Finance, 45 (1): 49-71. 


\section{William Davidson Institute Working Paper 444}

[21] Hart, Oliver, and John Moore (1995), "Debt and Seniority: An Analysis of the Role of Hard Claims in Constraining Management," American Economic Review, 85(3): $567-85$.

[22] Huang, Haizhou, and Chenggang Xu (1999), "Boundary of the Firm, Commitment, and R\&D Financing," mimeo, IMF and London School of Economics.

[23] Huang, Haizhou, and Chenggang Xu (2000), "Financial Contagion and the Lender of Last Resort Policy," mimeo, IMF and London School of Economics.

[24] Huang, Haizhou, and Chenggang Xu (2001), "Financial Intermediation and Liquidity Crisis," mimeo, IMF and London School of Economics.

[25] Jacklin, Charles J. and Sudipto Bhattacharya (1988), "Distinguishing Panics and Information-based Bank Runs: Welfare and Policy Implications," Journal of Political Economy, 96(3): 568-92.

[26] Kornai, Janos (1980), Economics of Shortage. Amsterdam: North-Holland.

[27] Lee, Kyu Uck (1998), Competition Policy, Deregulation and Economic Development. Seoul: KIET.

[28] McKinnon, Ronald, and H. Pill (1997), "Creditable Economic Liberalizations and Overborrowing," American Economic Review Papers and Proceedings, 87(2): 189-93.

[29] Nam, Sang-Woo (1994), "Korea's Financial Reform Since Early 1980s," in Gerald Caprio, Jr., Izak Atiyas, and James A Hansen (eds.), Financial Reform: Theory and Experience. Cambridge: Cambridge University Press.

[30] Nam, Sang Woo and Kim, Dong Won (1994), "The Principle Transactions Bank System in Korea,": Aoki, Masahiko and Patrick, Hugh (eds.), The Japanese main bank system: Its relevance for developing and transforming economies.. Oxford and New York: Oxford University Press, 1994, pages 450-93. 


\section{William Davidson Institute Working Paper 444}

[31] Park, Kyong-So (1997), "Chaebol Leveraged Management: Current Status and Reform Plans," mimeo, Korea Institute of Finance, September.

[32] Park, Yung Chul, and Dong-Won Kim (1994), "Korea: Development and Structural Change of the Banking System," in Hugh T. Patrick and Yung Chul Park (eds.), The Financial Development of Japan, Korea, and Taiwan: Growth, Repression, and Liberalization. Oxford: Oxford University Press.

[33] Postlewaite, Andrew, and Xavier Vives (1987), "Bank Runs as an Equilibrium Phenomenon," Journal of Political Economy, 95(3): 485-91.

[34] Qian, Yingyi, and Chenggang Xu (1998), "Innovation and Bureaucracy Under Soft and Hard Budget Constraints," Review of Economic Studies, 66(1): 151-64.

[35] Radelet, Steven, and Jeffrey Sachs (1998), "The East Asian Financial Crisis: Diagnosis, Remedies, Prospects," mimeo, Harvard University.

[36] Rochet, Jean-Charles, and Jean Tirole (1996), "Interbank Lending and Systemic Risk," Journal of Money, Credit, and Banking, 28(4): 733-62.

[37] Segal, Ilya (1998), "Monopoly and Soft Budget Constraint," Rand Journal of Economics, 29(3): 596-609.

[38] Semkow, Brian Wallace (1994), Taiwan's Capital Market Reform: The Financial and Legal Issues. Oxford: Clarendon Press.

[39] Shleifer, Andrei and Robert Vishny (1993), "Corruption," Quarterly Journal of Economics, 108: 599-617.

[40] Stern, Joseph J., Ji-hong Kim, Dwight H. Perkins, and Jung-ho Yoo (1995), Industrialization and the State: The Korean Heavy and Chemical Industry Drive. Cambridge, Mass; Harvard University Press. 


\section{William Davidson Institute Working Paper 444}

[41] von Hayek, Friedrich A. (1945), "Competition as a Discovery Procedure", in C. Nishiyama and K.R. Leube (ed.): The Essence of Hayek. Stanford, Calif.: Hoover Institution Press, 1984, pp. 254-65. 


\section{DAVIDSON INSTITUTE WORKING PAPER SERIES - Most Recent Papers}

The entire Working Paper Series may be downloaded free of charge at: www.wdi.bus.umich.edu

CURRENT AS OF 3/7/02

\begin{tabular}{|c|c|c|}
\hline Publication & Authors & Date \\
\hline No. 444: Financial Institutions, Contagious Risks, and Financial Crises & $\begin{array}{l}\text { Haizhou Huang and Chenggang } \\
\mathrm{Xu}\end{array}$ & Nov. 2001 \\
\hline No. 443: Banks as Catalysts for Industrialization & $\begin{array}{l}\text { Marco Da Rin and Thomas } \\
\text { Hellman }\end{array}$ & Oct. 2001 \\
\hline $\begin{array}{l}\text { No. 442: Bank-Based or Market-Based Financial Systems: Which is } \\
\text { Better? }\end{array}$ & Ross Levine & Feb. 2002 \\
\hline $\begin{array}{l}\text { No. 441: Migration and Regional Adjustment and Asymmetric Shocks } \\
\text { in Transition Economies }\end{array}$ & Jan Fidrmuc & Feb. 2002 \\
\hline $\begin{array}{l}\text { No. 440: Employment and Wages in Enterprises Under Communism } \\
\text { and in Transition: Evidence From Central Europe and Russia }\end{array}$ & $\begin{array}{l}\text { Swati Basu, Saul Estrin, and Jan } \\
\text { Svejnar }\end{array}$ & June 2000 \\
\hline No. 439: Small business in Russia: A Case Study of St. Petersburg & Alessandro Kihlgren & Jan. 2002 \\
\hline $\begin{array}{l}\text { No. 438: Foreign Direct Investment as Technology Transferred: } \\
\text { Some Panel Evidence from the Transition Economies }\end{array}$ & $\begin{array}{l}\text { Nauro F. Campos and Yuko } \\
\text { Kinoshita }\end{array}$ & Jan. 2002 \\
\hline No. 437: Whistleblowing, MNC's and Peace & Terry Morehead Dworkin & Feb. 2002 \\
\hline $\begin{array}{l}\text { No. 436: A Note on Measuring the Unofficial Economy in the Former } \\
\text { Soviet Republics }\end{array}$ & $\begin{array}{l}\text { Michael Alexeev and William } \\
\text { Pyle }\end{array}$ & Sept. 2001 \\
\hline $\begin{array}{l}\text { No. 435: The Ownership School vs. the Management School of State } \\
\text { Enterprise Reform: Evidence from China }\end{array}$ & David D. Li and Changqi Wu & Jan. 2002 \\
\hline $\begin{array}{l}\text { No. 434: The Effect of Ownership and Competitive Pressure on Firm } \\
\text { Performance in Transition Countries: Micro Evidence from Bulgaria, } \\
\text { Romania and Poland. }\end{array}$ & $\begin{array}{l}\text { Manuela Angelucci, Saul Estrin, } \\
\text { Jozef Konings, Zbigniew } \\
\text { Zolkiewski }\end{array}$ & Jan. 2002 \\
\hline No. 433: The End of Moderate Inflation in Three Transition Economies? & Josef C. Brada and Ali M. Kutan & Jan. 2002 \\
\hline $\begin{array}{l}\text { No. 432: What Drives the Speed of Job Reallocation During Episodes of } \\
\text { Massive Adjustment? }\end{array}$ & $\begin{array}{l}\text { Stepan Jurajda } \\
\text { Terrell }\end{array}$ & Jan. 2002 \\
\hline $\begin{array}{l}\text { No. } 431 \text { Forthcoming in: The Journal of Economic Perspectives, } \\
\text { "Competition and Corporate Governance in Transition," 16(2) Feb. } \\
\text { 2002. }\end{array}$ & Saul Estrin & Dec. 2001 \\
\hline $\begin{array}{l}\text { No. 430: Corporate Governance in the Cause of Peace: An } \\
\text { Environmental Perspective }\end{array}$ & Don Mayer & Jan. 2002 \\
\hline No. 429: Why do Governments Privatize? & $\begin{array}{l}\text { Loren Brandt, Hongbin Li, and } \\
\text { Joanne Roberts }\end{array}$ & Dec. 2001 \\
\hline No. 428: Testing Russia's Virtual Economy & Vlad Ivanenko & Dec. 2001 \\
\hline No. 427: War and the Business Corporation & Eric W. Orts & Dec. 2001 \\
\hline $\begin{array}{l}\text { No. 426: Partial Privatization and Firm Performance: Evidence from } \\
\text { India }\end{array}$ & Nandini Gupta & Dec. 2001 \\
\hline $\begin{array}{l}\text { No. 425: Direct Foreign Investments and Productivity Growth in } \\
\text { Hungarian Firms, 1992-1999 }\end{array}$ & Jérôme Sgard & Nov. 2001 \\
\hline $\begin{array}{l}\text { No. 424: Banking Passivity and Regulatory Failure in Emerging } \\
\text { Markets: Theory and Evidence from the Czech republic. }\end{array}$ & Jan Hanousek and Gerard Roland & July 2001 \\
\hline $\begin{array}{l}\text { No. 423: Conceptions of the Corporation and the Prospects of } \\
\text { Sustainable Peace }\end{array}$ & Jeffrey Nesteruk & Dec. 2001 \\
\hline No. 422: The Role of the Corporation in Fostering Sustainable Peace & Timothy Fort and Cindy Schipani & Nov. 2001 \\
\hline No. 421: Wage Arrears and the Distribution of Earnings in Russia & $\begin{array}{l}\text { Hartmut Lehmann and Jonathan } \\
\text { Wadsworth }\end{array}$ & Dec. 2001 \\
\hline $\begin{array}{l}\text { No. 420: Transferring Collective Knowledge: Collective and } \\
\text { Fragmented Teaching and Learning in the Chinese Auto Industry }\end{array}$ & $\begin{array}{l}\text { Jane Zhou, Jaideep Anand, and } \\
\text { Will Mitchell }\end{array}$ & Dec. 2001 \\
\hline $\begin{array}{l}\text { No. 419: Liberalization, Corporate Governance, and the Performance of } \\
\text { Newly Privatized Firms }\end{array}$ & $\begin{array}{l}\text { Narjess Boubakri, Jean-Claude } \\
\text { Cosset, and Omrane Guedhami }\end{array}$ & Dec. 2001 \\
\hline
\end{tabular}

